\title{
ВИКОРИСТАННЯ КОМП'ЮТЕРНИХ ТЕХНОЛОГІЙ В УМОВАХ ДИСТАНЦІЙНОГО НАВЧАННЯ ЗДОБУВАЧАМИ ВИЩОЇ ОСВІТИ МЕДИЧНОГО ПРОФІЛЮ
}

\author{
ОІ. Р. Волч, Г. І. Михайлишин
}

Тернопільський начіональний медичний університет імені І. Я. Горбачевського МОЗ України

PЕзЮмЕ. Професійна підготовка майбутніх медичних фахівців регламентована законодавчими документами і державними галузевими стандартами, які $€$ орієнтирами для цілеспрямованого планування й організації освітнього процесу, змісту професійної підготовки, вибору методів і засобів, прогнозування результатів тощо.

Мета - обґрунтування особливостей підготовки майбутніх медичних працівників до професійної діяльності 3 використанням сучасних інформаційно-комунікаційних технологій (IКT) в умовах дистанційного навчання.

Матеріал і методи. Опрацьовано праці вітчизняних і зарубіжних дослідників, вивчено особливості застосування IKT в умовах дистанційної освіти на основі результатів досліджень науковців і практичних працівників.

Результати. ІКТ активно впливають на процес навчання і виховання студентів, оскільки змінюють схему передавання знань і методи навчання.

Висновки. Удосконалення системи освіти на основі інформаційних технологій, широке впровадження в навчальний процес IKT привели до появи віртуальних університетів та відкритої системи освіти.

КЛючОВІ СлОВА: дистанційне навчання; інформаційні комп'ютерні технології; інформаційних технологій навчання; викладач; студент.

Вступ. На сьогодні, а особливо в період пандемії COVID-19, спостерігаємо інтенсивний розвиток онлайн-навчання. Використання в освітньому процесі IKT розкриває широкі можливості мережі Інтернет. Це дозволяє здобувачам вищої освіти безперервно навчатись у будь-якій точці світу, що особливо актуально для медичних закладів освіти, які працюють з іноземними студентами, отримувати доступ до віддалених інформаційних ресурсів, включаючи бази знань, електронні бібліотеки, вебінари та онлайн майстер-класи, експертні й навчальні системи тощо. Дистанційний курс навчання в умовах карантинних обмежень може бути призначений для доставки навчального матеріалу, розміщення виконаних завдань, так і для організації змішаного навчання. 3 огляду на це доволі актуальним $\epsilon$ дослідження різних типів взаємодії, а саме: «студент - контент», «студент - студент» і "студент - викладач», що забезпечує необхідні результати засвоєння навчального матеріалу $[2,5]$.

Мета - обґрунтування особливостей підготовки майбутніх медичних працівників до професійної діяльності з використанням сучасних інформаційно-комунікаційних технологій в умовах дистанційного навчання.

Матеріал і методи дослідження. Опрацьовано наукові доробки вітчизняних і зарубіжних дослідників, а також вивчено особливості застосування IКT в умовах дистанційної освіти на основі результатів досліджень науковців і практичних працівників.

Результати й обговорення. За результатами проведеного аналізу було виявлено, що уперше ДН в Україні започаткували Національний технічний університет «Харківський політехнічний ін- ститут», Харківський національний університет радіоелектроніки та Львівський інститут менеджменту ще в 1997 році. В подальшому в університетах України відкриваються центри (інститути) ДН [4-6].

ДН ґрунтується не лише на активності здобувачів вищої освіти, а й вимагає кваліфікованих викладачів, що забезпечать та організують спілкування, співтворчість, співробітництво та самостійну роботу студентів, де потрібно готувати та готуватися. Як показують дослідження, повного усвідомлення значення дистанційного навчання та ролі викладача для його забезпечення у більшості працівників закладів вищої освіти немає $[1,4]$.

Розглядаючи підготовку майбутніх медичних фахівців зазначимо, що діяльність лікарів неможлива без використання сучасних інформаційних технологій, які $\epsilon$ необхідним інструментом для медичних досліджень, в клінічній практиці та дозволить оволодіти навичками дослідницької діяльності з використанням сучасних IKT для самовдосконалення [5, 8].

Упровадження у навчально-виховний процес сучасних IKT з використанням активних форм і методів навчання (проблемне навчання; технологія розвивального навчання; технологія програмованого навчання; комп'ютерні технології навчання; технологія модульного навчання; технологія активізації творчої діяльності суб'єктів навчання тощо) дозволяє створити інтелектуальне інформаційне середовище, яке надає освітньому процесу більшої інтерактивності, наочності та розширює можливості освітнього процесу [7].

Таким чином, ДН розглядаєТься як цілеспрямовано організований процес синхронної та асин- 
Огляди літератури, оригінальні дослідження, погляд на проблему, випадок з практики, короткі повідомлення хронної інтерактивної взаємодії здобувачів вищої освіти між собою та із засобами навчання. При асинхронній взаємодії студент працює з навчальним матеріалом у зручний для себе час. При синхронній - викладач і студенти одночасно беруть участь в освітньому процесі (інтерактивне ТБ, аудіота відеоконференції, телевізійні лекції та консультації) $[5,3]$.

Висновки. Успіх впровадження IKT залежить від інформатизації навчального процесу. Саме ITH $\epsilon$ базою для реструктурування навчального процесу в умовах кредитно-модульної системи, що дає можливість майбутнім спеціалістам розширювати свої потенційні здібності, спонукає до активної навчальної, творчої і наукової діяльності, $є$ засобом активізації вивчення профільних предметів для конкретного типу освітньої установи форми і виду освіти.

\section{ЛІТЕРАТУРА}

1. Горбатюк Р. М. Мобільне навчання як нова технологія вищої освіти / Р. М. Горбатюк, Ю. Й. Тулашвілі // Науковий вісник Ужгородського національного університету. Серія : Педагогіка. Соціальна робота. Серія «Педагогіка, соціальна робота». - 2013. - Випуск 27. С. 31-34.

2. Долженко М. М. Актуальні питання дистанційної освіти та телемедицини / М. М. Долженко // Матеріали Всеукраїнської науково-методичної відеоконференції з міжнародною участю. - Запоріжжя, 2018. - 171 с.

3. Коневалова Н. Ю. Инновационная педагогическая деятельность в высшей школе / Н. Ю. Коневалова, И. В. Городецкая, И. И. Гарновская. - Витебск : ВГМУ, 2010.

4. Кухаренко В. М. Екстрене дистанційне навчання в Україні : монографія / Кухаренко В. М., Бондаренко В. В. - Харків, 2020. - 409 с.

\section{REFERENCES}

1. Horbatyuk, R.M., \& Tulashvili, Yu.Y. (2013). Mobilne navchannia yak nova tekhnolohiya vyshchoi osvity [Mobile learning as a new technology of higher education.]. Naukovyi visnyk Uzhhorodskoho natsionalnoho universytety. Seriya: Pedahohika, sotsialna robota - Scientific Bulletin of Uzhhorod National University. Series: Pedagogy, Social Work, 27, 31-34 [in Ukrainian].

2. Dolzhenko, M.M. (2018). Aktualni pytannya dystantsiynoyi osvity ta telemedytsyny. [Current issues of distance education and telemedicine]. Materialy Vseukrayinskoyi naukovo-metodychnoyi videokonferentsiyi z mizhnarodnoyu uchastyu.- Materials of the All-Ukrainian scientific-methodical videoconference with international participation. Zaporizhzhia [in Ukrainian].

3. Konevalova, N.Yu., Gorodetskaya, I.V., \& Garnovskaya, I.I. (2010). Innovatsionnaya pedagogicheskaya deyatelnost v vyshey shkolie [Innovative pedagogical activity in higher school]. Vitiebsk: VSMU [in Russian].

4. Kukharenko, V.M., \& Bondarenko, V.V. (2020). Ekstrene dystantsiyne navchannya v Ukrayini: monohrafia [Emergency distance learning in Ukraine: monograph]. Kharkiv [in Ukrainian].

5. Kucherenko, I. (2019) Psykholoho-pedahohichni osoblyvosti vyvchennya informatychnykh dystsyplin u medychnykh zakladakh vyshchoyi osvity z vykorystannyam dys-

tantsiynoho navchannya. [Psychological and pedagogical features of the study of computer science disciplines in medical institutions of higher education using distance learning]. Pedahohichni nauky: teoria, istoria, inovatsiyni tekhnolohii - Pedagogical Sciences: Theory, History, Innovative Technologies, 1, 28-39 [in Ukrainian].

6. Mikhalchenko, M. (2001) Osvita i nauka: poshuky novykh paradyhm modernizatsiyi. [Education and science: the search for new paradigms of modernization]. Vyshcha osvita Ukrainy - Higher Education of Ukraine, 2, 14-23 [in Ukrainian].

7. Romanyshyna, L.M. (2006). Suchasni pedahohichni tekhnolohiyi pidhotovky maybutnikh fakhivtsiv. Problemy osvity [Modern pedagogical technologies for training future professionals]. L.M. Romanyshyna (Eds.), Problemy osvity - Problems of education. Kyiv: Vydavnytstvo Nauk.Metod. Tsentru Vyshchoi Osvity [in Ukrainian].

8. Saenko, M.S., \& Morokhovets, G.Y. (2018). Vykorystannya informatsiyno-komunikatsiynykh tekhnolohiy u maybutniy profesiyniy diyalnosti $v$ protsesi vyvchennya medychnoyi informatyky [The use of information and communication technologies in future professional activities in the study of medical informatics]. Imidzh suchasnoho pedahoha - Image of a Modern Teacher, 3, 18-21 [in Ukrainian]. 
Тернопольский национальный медицинский университет имени И. Я. Горбачевского МОз Украины

РЕЗЮМЕ. Профессиональная подготовка будущих медицинских специалистов регламентирована законодательными документами и государственными отраслевыми стандартами, которые являются ориентирами педагогам для целенаправленного планирования и организации образовательного процесса, содержания профессиональной подготовки, выбора методов и средств, прогнозирования результатов и т.п.

Цель - обоснование особенностей подготовки будущих медицинских работников к профессиональной деятельности с использованием современных информационно-коммуникационных технологий (ИКТ) в условиях дистанционного обучения.

Материал и методы. Обработаны труды отечественных и зарубежных исследователей, а также изучены особенности применения ИКТ в условиях дистанционного образования на основе результатов исследований ученых и практических работников.

Результаты. ИКТ осуществляют активное воздействие на процесс обучения и воспитания студентов, поскольку изменяют схему передачи знаний и методы обучения.

Выводы. Усовершенствование системы образования на основе информационных технологий, широкое внедрение в учебный процесс ИКТ привело к появлению виртуальных университетов и открытой системы образования.

КЛЮЧЕВЫЕ СЛОВА: дистанционное обучение; информационные компьютерные технологии; информационные технологии обучения; преподаватель; студент.

\section{USE OF COMPUTER TECHNOLOGIES IN THE CONDITIONS OF DISTANCE LEARNING BY HIGHER EDUCATION PRODUCTS OF THE MEDICAL PROFILE}

\section{Horbachevsky Ternopil National Medical University \\ OI. R. Volch, G. I. Mykhailyshyn}

SUMMARY. Professional training of future medical specialists is regulated by legislative documents and state industry standards, which are guidelines for educators for purposeful planning and organization of the educational process, the content of professional training, choice of methods and tools, forecasting results, etc.

The aim - to substantiate the peculiarities of training future medical workers for professional activities with the use of modern information and communication technologies in distance learning.

Material and Methods. Works of domestic and foreign researchers were processed. Also, the features of the use of ICT in distance education were studied on the basis of research results of scientists and practitioners.

Results. ICTs have an active influence on the process of teaching and educating students, as they change the scheme of knowledge transfer and teaching methods.

Conclusions. Improving the education system, based on information technology, the widespread introduction of ICT in the educational process has led to the emergence of virtual universities and an open education system.

KEY WORDS: distance learning; information computer technologies; information technologies of training; teacher; student.

Отримано 12.03.2021 